\title{
HOLOCENE VARIATIONS OF RADIOCARBON RESERVOIR AGES IN A MEDITERRANEAN LAGOONAL SYSTEM
}

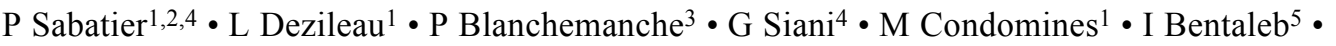 \\ G Piquès ${ }^{3}$
}

\begin{abstract}
To obtain a precise radiocarbon Holocene chronology in coastal areas, it is necessary to estimate the modern ${ }^{14} \mathrm{C}$ reservoir age $\mathrm{R}(\mathrm{t})$ and its possible variations with time in relation to paleoenvironmental changes. The modern reservoir ${ }^{14} \mathrm{C}$ age was estimated by comparing AMS ${ }^{14} \mathrm{C}$ ages of 2 recent mollusk shells found in sediment cores sampled in the Palavasian lagoonal system (south of France) with ages derived from ${ }^{210} \mathrm{~Pb}$ and ${ }^{137} \mathrm{Cs}$ data and historical accounts of identifiable storm events. The calculated modern $\mathrm{R}(\mathrm{t})$ value of $943 \pm 25{ }^{14} \mathrm{C}$ yr is about $600 \mathrm{yr}$ higher than the global mean sea surface reservoir age. This high value, probably due to the relative isolation of the lagoon from marine inputs, is in good agreement with other R(t) estimates in Mediterranean lagoonal systems (Zoppi et al. 2001; Sabatier et al. 2008). ${ }^{14} \mathrm{C}$ ages were also obtained on a series of Holocene mollusk shells sampled at different depths of the $\sim 8$-m-long core PB06. Careful examination of the ${ }^{14} \mathrm{C}$ ages versus depth relationships suggests that $\mathrm{R}(\mathrm{t})$ in the past was lower and similar to the value presently measured in the Gulf of Lion $\left(618 \pm 30{ }^{14} \mathrm{C}\right.$ yr, Siani et al. 2000). The change in $\mathrm{R}(\mathrm{t})$ from 618 to $943 \mathrm{yr}$ is thought to result from final closure of the coastal lagoon by the sandy barrier, due to the along-shore sediment transfer.
\end{abstract}

\section{INTRODUCTION}

To determine the Holocene timescale, absolute chronology is usually based on radiocarbon measurements of carbonaceous samples, allowing accurate paleoenvironmental and archaeological interpretations. However, when the ${ }^{14} \mathrm{C}$ method is applied to date samples equilibrated in marine or continental bodies of water, it requires a correction, called the reservoir age correction. While the correction for marine reservoir age is well established, many recent studies have focused on climate records in coastal areas, which are strongly influenced by continental river inputs (Spennemann and Head 1998; Oldfield et al. 2003; Dezileau et al. 2005; Sabatier et al. 2008; Sorrel et al. 2009). Indeed, a sample from an estuarine or lagoonal system could be affected by a reservoir age offset (R) due to a mixture between the marine reservoir effect (MRE) and the hardwater effect (HWE) (e.g. Little 1993). The reservoir age of the global mixed marine surface layer is a quantitative measure of the offset between the activities of marine ${ }^{14} \mathrm{C}$ variations in response to atmospheric ${ }^{14} \mathrm{C}$ changes. It is induced by the significant lapse of time required for $\mathrm{CO}_{2}$ exchange between the atmosphere and the ocean (i.e. to the long residence time of carbon in the ocean, compared to the ${ }^{14} \mathrm{C}$ half-life) (Stuiver et al. 1986; Stuiver and Braziunas 1993). The HWE refers also to the dilution of ${ }^{14} \mathrm{C}$ activity in the marine reservoir by the influx of ${ }^{14} \mathrm{C}$-free inorganic carbon originating from subaerial dissolution of old carbonate rocks (Spennemann and Head 1998).

The pre-industrial global reservoir age is estimated as $405 \pm 22{ }^{14} \mathrm{C}$ yr and a time-dependent correction is available by using the Marine 04 calibration curve (Hughen et al. 2004). Several studies have suggested the possibility of significant deviations in regional marine reservoir signature from this average value (Goodfriend and Flessa 1997; Ingram and Southon 1997; Siani et al. 2001; Reimer and McCormac 2002; Southon et al. 2002; Fontugne et al. 2004). The reservoir age in coastal areas

\footnotetext{
${ }^{1}$ Université Montpellier 2, Geosciences Montpellier, CNRS/INSU, UMR 5243, Montpellier, France.

${ }^{2}$ Corresponding author: Email: pierre.sabatier@u-psud.fr.

${ }^{3}$ Université Montpellier 3, Laboratoire d'Archéologie des Sociétés Méditerranéennes, CNRS, UMR 5140, Lattes, France.

${ }^{4}$ Université Paris-Sud, Laboratoire des Interactions et de la Dynamique des Environnements de Surface, CNRS/INSU, UMR 8148 , Orsay, France.

${ }^{5}$ Université Montpellier 2, Institut des Sciences de l'Evolution de Montpellier, CNRS, UMR 5554, Montpellier, France. Also: Laboratoire des Sciences du Climat et de l'Environnement LSCE/IPSL UMR CNRS-CEA-UVSQ, UMR 1572, Bât. 12, Avenue de la Terrasse, 91198 Gif sur Yvette Cedex, France.
} 
may also vary with time in relation to environmental changes, which would modify the respective proportion of marine and freshwater inputs. These changes include modification of river discharge rates and variation of marine inputs due to the build-up of a delta or due to a change in the sandy barrier morphology. Some examples of lagoonal environments in the Mediterranean area show that $\mathrm{R}(\mathrm{t})$ is high and could vary between 600 to $1200 \mathrm{yr}$ (Zoppi et al. 2001; Sabatier et al. 2008). These R(t) values can be estimated by comparing dated pre-industrial marine shells of known age or by comparing the ${ }^{14} \mathrm{C}$ ages of lagoonal mollusks with the ages of sediment derived using ${ }^{210} \mathrm{~Pb} /{ }^{137} \mathrm{Cs}$ methods or paleostorm events dated from historical accounts. The latter method is applied in this study.

This work is a part of the ECLICA project (Dezileau et al. 2005), one of the aims of which was to estimate the modern $\mathrm{R}(\mathrm{t})$ in a coastal lagoon of the northwestern Mediterranean basin and to understand the relation between paleoenvironmental changes and variations in $R(t)$. When appropriate $\mathrm{R}(\mathrm{t})$ corrections are applied, a precise and high-resolution chronology of the studied sediment core can be derived. The resulting chronology provides valuable information on the relationship between climate, sediment dynamics, and the implications on human society, in an area inhabited since prehistoric times (Sabatier et al. 2010).

\section{LOCATION OF THE SAMPLING SITE}

This study focuses on the Palavasian lagoonal complex located west of the Rhône Delta, in the central part of the Gulf of Lion, $10 \mathrm{~km}$ south of Montpellier in southern France (Figure 1). These coastal wetlands are the result of the interaction between a process of shoreline regularization by migration of littoral barriers and the filling of these areas by fluvial and marine particulate inputs (Certain et al. 2004). This area consists of several small, shallow $(<1 \mathrm{~m})$ lagoons enclosed by a narrow sandy barrier to the south and to the north by calcareous Mesozoic hills. Most of the sediments supplied to the area are carried during flash-flood events by 2 short coastal rivers (Mosson and Lez). This wetland complex is now crossed by an artificial navigation channel built in the 18th century. In some places, the sandy barrier is less than $60 \mathrm{~m}$ wide and $3 \mathrm{~m}$ high above the mean sea level. This implies a temporary but strong marine influence during storm events (Dezileau et al. 2005; Sabatier et al. 2008).

The PB06 core is $7.9 \mathrm{~m}$ long and was collected in Pierre Blanche Lagoon (PBL), in the southern part of the Palavasian lagoonal complex (Figure 1), in March 2006 with the Uwitec coring platform (University of Chambéry and Laboratoire des Sciences du Climat et de l'Environnement). Twentyeight lagoonal shells (Cerastoderma Glaucum, Abra Ovata, and Rissoa sp.) were selected on core PB06 at different depths for ${ }^{14} \mathrm{C}$ age determination. In addition, another shell recovered at $62 \mathrm{~cm}$ depth from a nearby core (PRO 15, sampled $<100 \mathrm{~m}$ away from PB06) was also dated.

\section{ANALYTICAL METHODS}

${ }^{14} \mathrm{C}$ analyses were conducted at the Laboratoire de Mesure ${ }^{14} \mathrm{C}$ (LMC14) on the ARTEMIS accelerator mass spectrometer (Accélérateur pour la Recherche en sciences de la Terre, Environnement, Muséologie Installé à Saclay) in the CEA Institute at Saclay (Atomic Energy Commission). These ${ }^{14} \mathrm{C}$ analyses were done with the standard procedures described by Tisnérat-Laborde et al. (2001). ${ }^{14} \mathrm{C}$ ages were converted to calendar years using the CALIB 5.0.2 calibration program (Stuiver and Reimer 1993; Reimer and Reimer 2001). X-ray diffraction (XRD) analyses of shells were performed at the University of Montpellier 2 (Laboratoire de Mesures Physique).

Dating of sedimentary layers was carried out using ${ }^{210} \mathrm{~Pb}$ and ${ }^{137} \mathrm{Cs}$ methods on a centennial timescale. Both nuclides together with $\mathrm{U}, \mathrm{Th}$, and ${ }^{226} \mathrm{Ra}$ were determined by gamma spectrometry at the 


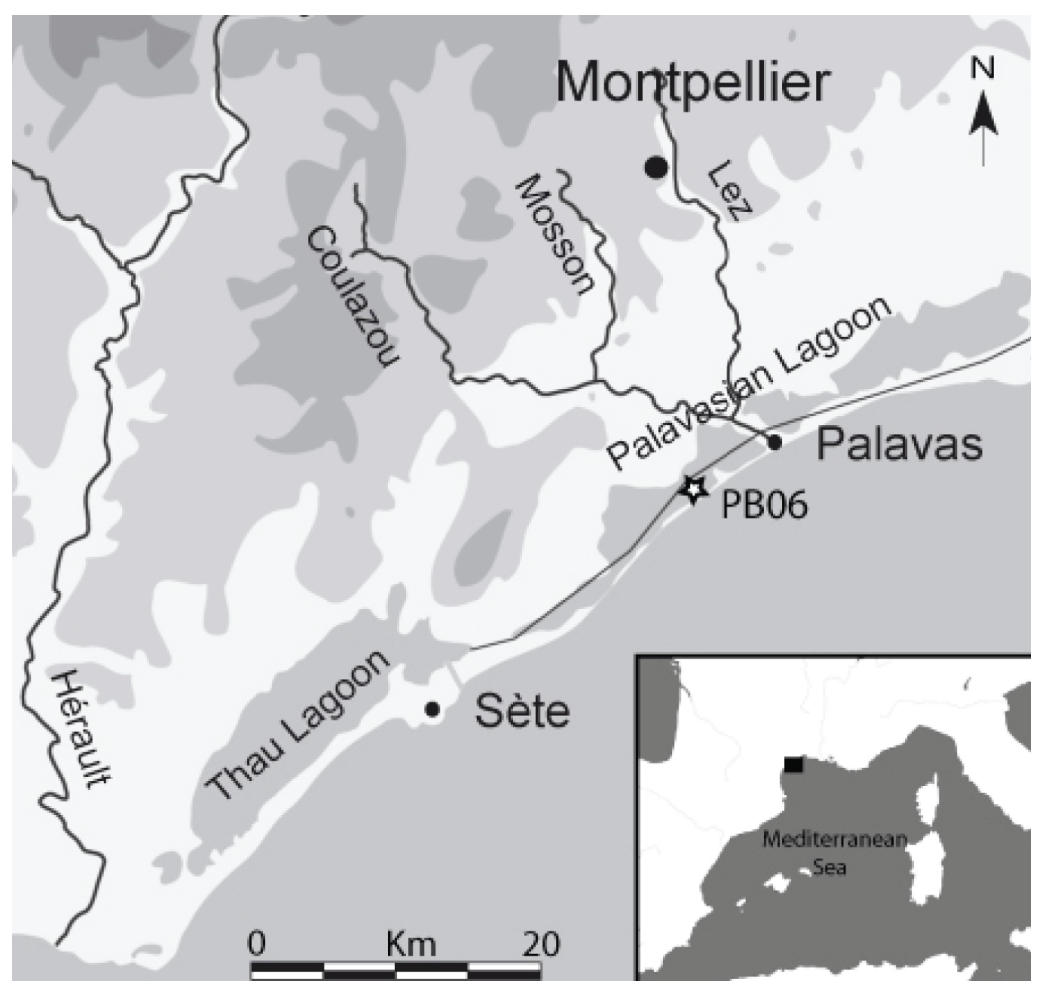

Figure 1 Map of the western Mediterranean Sea and the central part of the Gulf of Lion (south of France) with the location of PB06 core sampled in Pierre Blanche Lagoon (part of the Palavasian lagoonal complex).

Géosciences Montpellier Laboratory (Montpellier, France). The 1-cm-thick sediment layers were washed in deionized water and sieved. The fraction smaller than $1 \mathrm{~mm}$ was then finely crushed after drying, and transferred into small gas-tight PETP (polyethylene terephtalate) tubes (internal height and diameter of 38 and $14 \mathrm{~mm}$, respectively), and stored for more than 3 weeks to ensure equilibrium between ${ }^{226} \mathrm{Ra}$ and ${ }^{222} \mathrm{Rn}$. The activities of the nuclides of interest were determined using a Canberra Ge well detector and compared with the known activities of an in-house standard. Activities of ${ }^{210} \mathrm{~Pb}$ were determined by integrating the area of the $46.5-\mathrm{keV}$ photo-peak. ${ }^{226} \mathrm{Ra}$ activities were determined from the average of values derived from the $186.2-\mathrm{keV}$ peak of ${ }^{226} \mathrm{Ra}$ and the peaks of its progeny in secular equilibrium with ${ }^{214} \mathrm{~Pb}(295$ and $352 \mathrm{keV})$ and ${ }^{214} \mathrm{Bi}(609 \mathrm{keV})$. In each sample, the $\left({ }^{210} \mathrm{~Pb}\right.$ unsupported) excess activities were calculated by subtracting the $\left({ }^{226} \mathrm{Ra}\right.$ supported) activity from the total $\left({ }^{210} \mathrm{~Pb}\right)$ activity. (Note that, throughout this paper, parentheses denote activities.) A self-absorption correction based on major element composition and sample density was systematically applied for all photo-peaks, using a modified version of the program written by J Faïn (Pilleyre et al. 2006). The self-absorption corrections were rather small, even for the lowenergy peaks $(<4 \%)$.

\section{RESULTS}

Since Goldberg (1963) first established a method based on ${ }^{210} \mathrm{~Pb}$ chronology, this procedure has provided a very useful tool for dating recent sediments. Several ${ }^{210} \mathrm{~Pb}$ models were later proposed, allowing a precise calculation of sedimentation rates (e.g. Appleby and Oldfield 1978, 1992). In the 
simplest model, the initial $\left({ }^{210} \mathrm{~Pb}\right)_{\mathrm{ex}}$ is assumed constant and thus $\left({ }^{210} \mathrm{~Pb}\right)_{\mathrm{ex}}$ at any time is given by the radioactive decay law. In the CFCS ("constant flux, constant sedimentation rate") model (Goldberg 1963; Krishnaswamy et al. 1971), the ${ }^{210} \mathrm{~Pb}$ flux and sedimentation rate are assumed to be constant. The sedimentation rate in Pierre Blanche Lagoon is clearly variable due to the near-instantaneous sedimentation of sandy storm deposits; however, the CFCS model can be applied when typical lagoonal conditions prevail (Sabatier et al. 2008). Using the CFCS model, the ${ }^{210} \mathrm{~Pb}$ data indicate a sedimentation rate of $2.65 \pm 0.2 \mathrm{~mm} / \mathrm{yr}$ (Figure 2, Table 1).

The most common dating method based on ${ }^{137} \mathrm{Cs}$ data (Robbins and Edgington 1975) assumes that the depth of maximum ${ }^{137} \mathrm{Cs}$ activity in the sediment corresponds to the maximum atmospheric production in 1963. On the other hand, the 1986 Chernobyl fallout is used to date the most recent part of cores (Appleby 1991). A property of Cs is its high mobility in marine sediments, with a preferential downward diffusive transport in porewater (Radakovitch et al. 1999). Despite the potential Cs mobility by diffusive transport, leading to the spreading of the Cs peak, we can see in Figure 2 that the ${ }^{137} \mathrm{Cs}$ profile shows a clear maximum corresponding to 1963 . The ${ }^{137} \mathrm{Cs}$ activity depth profile thus gives accumulation rates of 2.6 and $3 \mathrm{~mm} / \mathrm{yr}$, respectively, for the 1963 and 1986 depths (Figure 2 , Table 1). These rates are in good agreement with ${ }^{210} \mathrm{~Pb}$ data.

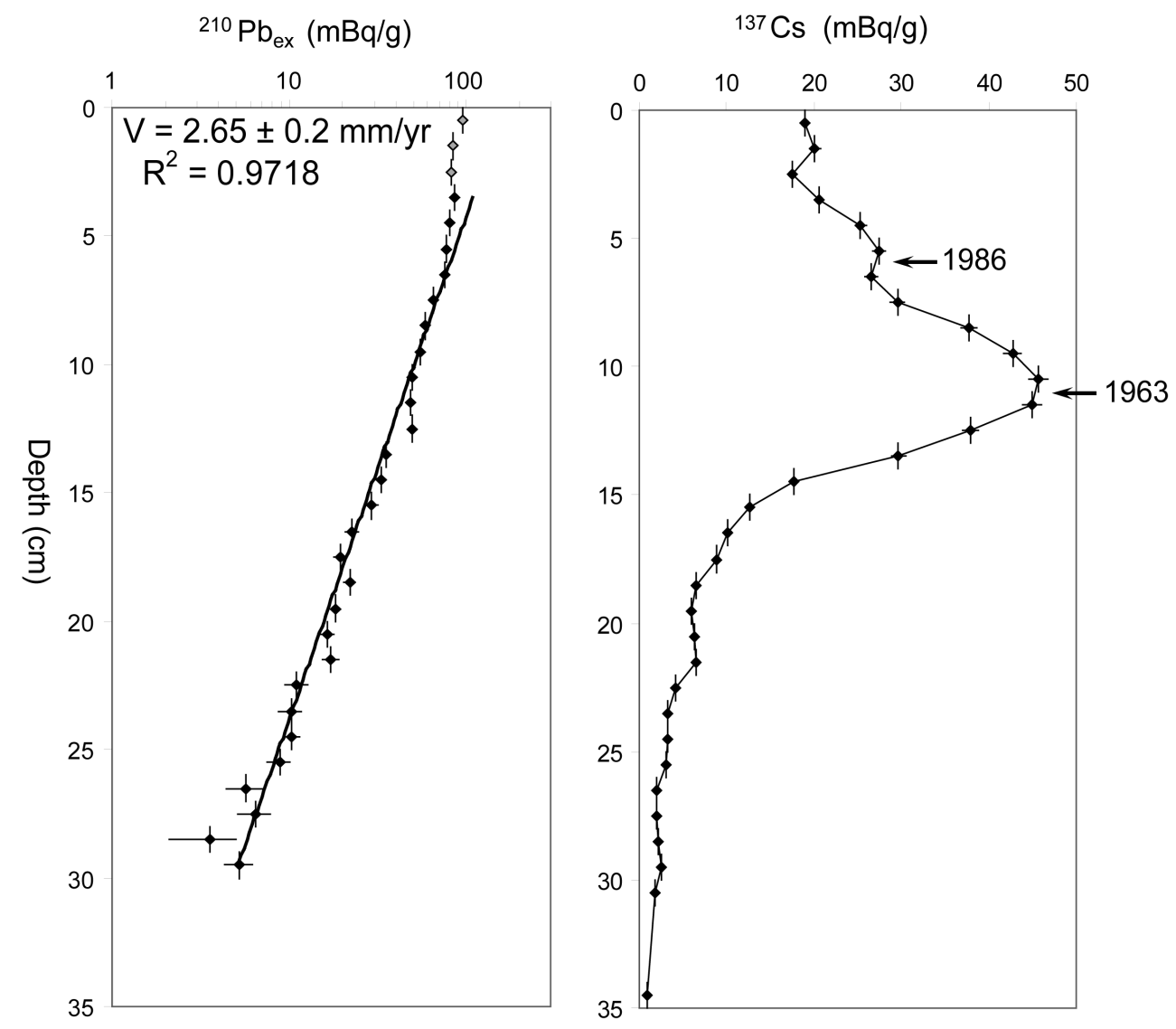

Figure $2{ }^{210} \mathrm{~Pb}_{\mathrm{ex}}$ and ${ }^{137} \mathrm{Cs}$ activity depth profiles in core $\mathrm{PB} 06$ from Pierre Blanche Lagoon. ${ }^{210} \mathrm{~Pb}$ excess disappears at around $30 \mathrm{~cm}$. Using the CFCS model, the ${ }^{210} \mathrm{~Pb}$ data indicate a sedimentation rate of $2.65 \pm 0.2 \mathrm{~mm} / \mathrm{yr}$. The ${ }^{137} \mathrm{Cs}$ activity depth profile displays 2 peaks at 6 and $11 \mathrm{~cm}$, resulting in accumulation rates of 2.6 and $3 \mathrm{~mm} / \mathrm{yr}$, respectively, for the 1963 and 1986 depths. 
Table 1 Activities of radionuclides in core PB06.

\begin{tabular}{|c|c|c|c|c|}
\hline $\begin{array}{l}\text { Depth } \\
(\mathrm{cm})\end{array}$ & $\begin{array}{l}{ }^{210} \mathrm{~Pb} \\
(\mathrm{mBq} / \mathrm{g})\end{array}$ & $\begin{array}{l}{ }^{226} \mathrm{Ra} \\
(\mathrm{mBq} / \mathrm{g})\end{array}$ & $\begin{array}{l}{ }^{210} \mathrm{~Pb}_{\mathrm{ex}} \\
(\mathrm{mBq} / \mathrm{g})\end{array}$ & $\begin{array}{l}{ }^{137} \mathrm{Cs} \\
(\mathrm{mBq} / \mathrm{g})\end{array}$ \\
\hline 0.5 & $113.49 \pm 2.47$ & $19.12 \pm 0.32$ & $94.38 \pm 2.49$ & $18.89 \pm 0.53$ \\
\hline 1.5 & $102.50 \pm 2.93$ & $19.47 \pm 0.43$ & $83.03 \pm 2.97$ & $20.09 \pm 0.68$ \\
\hline 2.5 & $101.23 \pm 2.22$ & $19.73 \pm 0.20$ & $81.50 \pm 2.23$ & $17.54 \pm 0.45$ \\
\hline 3.5 & $104.61 \pm 2.59$ & $18.94 \pm 0.26$ & $85.67 \pm 2.60$ & $20.60 \pm 0.56$ \\
\hline 4.5 & $99.11 \pm 2.66$ & $19.05 \pm 0.23$ & $80.06 \pm 2.67$ & $25.36 \pm 0.64$ \\
\hline 5.5 & $99.47 \pm 2.50$ & $21.78 \pm 0.25$ & $77.68 \pm 2.51$ & $27.40 \pm 0.70$ \\
\hline 6.5 & $97.17 \pm 2.16$ & $21.97 \pm 0.23$ & $75.20 \pm 2.18$ & $26.55 \pm 0.67$ \\
\hline 7.5 & $83.06 \pm 2.10$ & $17.61 \pm 0.23$ & $65.45 \pm 2.12$ & $29.53 \pm 0.75$ \\
\hline 8.5 & $76.28 \pm 1.93$ & $18.18 \pm 0.22$ & $58.10 \pm 1.95$ & $37.78 \pm 0.93$ \\
\hline 9.5 & $72.25 \pm 1.97$ & $17.77 \pm 0.22$ & $54.48 \pm 1.98$ & $42.73 \pm 1.04$ \\
\hline 10.5 & $66.90 \pm 2.03$ & $17.03 \pm 0.22$ & $49.87 \pm 2.04$ & $45.63 \pm 1.11$ \\
\hline 11.5 & $65.30 \pm 1.91$ & $17.18 \pm 0.21$ & $48.12 \pm 1.92$ & $44.91 \pm 1.09$ \\
\hline 12.5 & $65.68 \pm 2.01$ & $16.48 \pm 0.22$ & $49.20 \pm 2.03$ & $37.94 \pm 0.93$ \\
\hline 13.5 & $55.60 \pm 2.02$ & $20.13 \pm 0.42$ & $35.47 \pm 2.06$ & $29.69 \pm 0.82$ \\
\hline 14.5 & $49.23 \pm 1.54$ & $16.04 \pm 0.19$ & $33.20 \pm 1.55$ & $17.67 \pm 0.46$ \\
\hline 15.5 & $48.99 \pm 1.65$ & $19.70 \pm 0.22$ & $29.28 \pm 1.66$ & $12.71 \pm 0.36$ \\
\hline 16.5 & $41.71 \pm 1.13$ & $19.10 \pm 0.21$ & $22.61 \pm 1.15$ & $10.13 \pm 0.27$ \\
\hline 17.5 & $39.20 \pm 1.33$ & $19.75 \pm 0.28$ & $19.45 \pm 1.36$ & $8.89 \pm 0.31$ \\
\hline 18.5 & $39.27 \pm 1.73$ & $17.18 \pm 0.24$ & $22.09 \pm 1.75$ & $6.58 \pm 0.24$ \\
\hline 19.5 & $35.32 \pm 1.57$ & $17.17 \pm 0.33$ & $18.15 \pm 1.60$ & $5.98 \pm 0.32$ \\
\hline 20.5 & $36.13 \pm 1.53$ & $19.65 \pm 0.32$ & $16.48 \pm 1.57$ & $6.39 \pm 0.32$ \\
\hline 21.5 & $35.16 \pm 0.95$ & $18.04 \pm 0.18$ & $17.13 \pm 0.97$ & $6.45 \pm 0.19$ \\
\hline 22.5 & $31.08 \pm 1.33$ & $20.03 \pm 0.30$ & $11.05 \pm 1.37$ & $4.16 \pm 0.23$ \\
\hline 23.5 & $29.00 \pm 1.27$ & $18.78 \pm 0.28$ & $10.22 \pm 1.30$ & $3.29 \pm 0.21$ \\
\hline 24.5 & $28.83 \pm 1.32$ & $18.48 \pm 0.32$ & $10.35 \pm 1.35$ & $3.26 \pm 0.24$ \\
\hline 25.5 & $28.18 \pm 1.43$ & $19.40 \pm 0.33$ & $8.78 \pm 1.47$ & $3.06 \pm 0.24$ \\
\hline 26.5 & $22.58 \pm 0.93$ & $16.92 \pm 0.20$ & $5.67 \pm 0.95$ & $1.98 \pm 0.11$ \\
\hline 27.5 & $22.22 \pm 0.83$ & $15.77 \pm 0.20$ & $6.45 \pm 0.85$ & $1.96 \pm 0.11$ \\
\hline 28.5 & $24.57 \pm 1.05$ & $20.98 \pm 0.23$ & $3.58 \pm 1.08$ & $2.14 \pm 0.16$ \\
\hline 29.5 & $26.08 \pm 1.15$ & $20.85 \pm 0.23$ & $5.23 \pm 1.17$ & $2.48 \pm 0.20$ \\
\hline 30.5 & $21.84 \pm 1.21$ & $21.60 \pm 0.30$ & $0.24 \pm 1.25$ & $1.83 \pm 0.18$ \\
\hline 34.5 & $20.88 \pm 1.13$ & $21.23 \pm 0.28$ & $-0.35 \pm 1.16$ & $0.94 \pm 0.14$ \\
\hline
\end{tabular}

Conventional ${ }^{14} \mathrm{C}$ measurements performed on shells from core PB06 result in model ages covering a time interval between 7600 to $1050 \mathrm{BP}$. The ${ }^{14} \mathrm{C}$ ages are expressed in Table 2 as BP following Stuiver and Polach (1977). The XRD analysis of the shells shows a $>99 \%$ aragonite composition, excluding any recrystallization process. These conventional ages display 2- $\sigma$ inversions between 139 and $173 \mathrm{~cm}$ and between 567 and $610 \mathrm{~cm}$, respectively. Moreover, a large age plateau is observed between 264 and $289 \mathrm{~cm}$. The dated mollusks live within the first $5 \mathrm{~cm}$ of sediment. Therefore, bioturbation or mollusk habitat depth cannot explain these inversions. This uncalibrated ${ }^{14} \mathrm{C}$ chronology adopted for core PB06 allows us to estimate important reservoir age fluctuations since the modern period, and/or variations in the sedimentation rate. 
Table $2{ }^{14} \mathrm{C}$ data for mollusk shells from cores POR 15 (1 sample) and PB06. ${ }^{14} \mathrm{C}$ ages are calibrated in the last 2 columns using the Marine04 calibration curve with different values of the reservoir age $\Delta R$. Age models 1 and 2 correspond to Figure $4 \mathrm{~b}$ and $4 \mathrm{c}$, respectively. Age model 1 uses a constant $\Delta \mathrm{R}$ of $605 \pm 30 \mathrm{yr}$, while Age model 2 dates are calibrated with a $\Delta \mathrm{R}$ of $605 \pm 30 \mathrm{yr}$ for the upper 5 samples and with $\Delta \mathrm{R}$ of $245 \pm 30 \mathrm{yr}$ (see text for details).

\begin{tabular}{|c|c|c|c|c|c|c|}
\hline Lab code & $\begin{array}{l}\text { Depth } \\
(\mathrm{cm})\end{array}$ & Species & $\begin{array}{l}\text { Conventional } \\
\text { age BP }\end{array}$ & $\begin{array}{l}\text { Marine04 } \\
(\text { cal BP, } 2 \sigma)\end{array}$ & $\begin{array}{l}\text { Age model } 1 \\
(\text { cal BP, } 2 \sigma)\end{array}$ & $\begin{array}{l}\text { Age model } 2 \\
(\text { cal BP, } 2 \sigma)\end{array}$ \\
\hline SacA 6253 & 20 & Cerastoderma $g$. & $1055 \pm 30$ & $551-673$ & $0-149$ & $0-149$ \\
\hline SacA 6254 & 83 & Cerastoderma g. & $1285 \pm 30$ & $745-907$ & $255-430$ & $255-430$ \\
\hline SacA-10833 & 127 & Cerastoderma $g$. & $1780 \pm 30$ & $1264-1389$ & $644-818$ & $644-818$ \\
\hline SacA 6160 & 131 & Cerastoderma g. & $1955 \pm 30$ & $1404-1597$ & $776-989$ & $776-989$ \\
\hline SacA 10720 & 139 & Cerastoderma $g$. & $2090 \pm 30$ & $1562-1771$ & $929-1143$ & $929-1143$ \\
\hline SacA 6161 & 173 & Cerastoderma g. & $1645 \pm 30$ & $1133-1277$ & $531-674$ & $842-1054$ \\
\hline SacA 10834 & 199 & Cerastoderma $g$. & $1820 \pm 30$ & $1283-1447$ & $670-871$ & $1029-1249$ \\
\hline SacA 6162 & 225 & Cerastoderma g. & $2100 \pm 30$ & $1578-1787$ & $940-1157$ & $1301-1505$ \\
\hline SacA 10835 & 255 & Cerastoderma $g$. & $2615 \pm 30$ & 2169-2365 & $1455-1696$ & $1881-2113$ \\
\hline SacA 6163 & 264 & Cerastoderma g. & $3090 \pm 35$ & $2757-2959$ & $2012-2290$ & $2447-2726$ \\
\hline SacA 10722 & 267 & Cerastoderma $g$. & $2950 \pm 30$ & $2771-2794$ & 1858-2094 & $2300-2572$ \\
\hline SacA 10725 & 267 & Abra ovata & $3045 \pm 30$ & $2737-2895$ & $1955-2243$ & $2385-2691$ \\
\hline SacA 6164 & 278 & Cerastoderma $g$. & $3050 \pm 30$ & $2741-2903$ & $1966-2253$ & $2390-2695$ \\
\hline SacA 10723 & 278 & Cerastoderma g. & $3230 \pm 30$ & $2935-3165$ & $2163-2429$ & $2687-2855$ \\
\hline SacA 10724 & 289 & Cerastoderma g. & $3065 \pm 30$ & 2749-2920 & $1986-2268$ & $2417-2708$ \\
\hline SacA 6255 & 311 & Cerastoderma g. & $3145 \pm 30$ & $2831-3045$ & $2101-2319$ & $2515-2760$ \\
\hline SacA 6165 & 354 & Rissoa & $3360 \pm 30$ & $3131-3331$ & $2340-2618$ & $2768-3021$ \\
\hline SacA 6166 & 398 & Cerastoderma $g$. & $3805 \pm 30$ & $3647-3846$ & $2867-3150$ & $3347-3562$ \\
\hline SacA 6256 & 451 & Cerastoderma g. & $4105 \pm 30$ & $4053-4279$ & $3266-3493$ & $3689-3949$ \\
\hline SacA 6257 & 498 & Cerastoderma g. & $4400 \pm 30$ & $4432-4678$ & $3616-3861$ & $4091-4373$ \\
\hline SacA 6167 & 531 & Cerastoderma g. & $5050 \pm 30$ & $5300-5484$ & $4497-4786$ & $4944-5258$ \\
\hline SacA 6168 & 567 & Cerastoderma g. & $4965 \pm 35$ & $5236-5434$ & $4377-4653$ & $4825-5123$ \\
\hline SacA 6169 & 610 & Cerastoderma g. & $5440 \pm 35$ & $5719-5901$ & $4976-5275$ & $5452-5648$ \\
\hline SacA 6258 & 635 & Abra ovata & $5645 \pm 30$ & $5946-6159$ & $5288-5509$ & $5658-5883$ \\
\hline SacA 6170 & 657 & Cerastoderma $g$. & $5855 \pm 35$ & $6189-6360$ & $5507-5721$ & $5900-6148$ \\
\hline SacA 6171 & 684 & Cerastoderma g. & $2120 \pm 60$ & $1548-1852$ & $926-1220$ & $1282-1567$ \\
\hline SacA 6260 & 710 & Abra ovata & $6220 \pm 30$ & $6568-6754$ & $5906-6146$ & $6286-6484$ \\
\hline SacA 6259 & 744 & Abra ovata & $7175 \pm 30$ & 7569-7708 & $6966-7209$ & 7354-7540 \\
\hline SacA 6261 & 758 & Abra ovata & $7600 \pm 30$ & $7976-8149$ & $7417-7565$ & $7711-7923$ \\
\hline
\end{tabular}

\section{DISCUSSION}

\section{Modern Reservoir Age Estimation}

Compared to the average modern ${ }^{14} \mathrm{C}$ marine reservoir age $(\mathrm{R}(\mathrm{t}))=405 \pm 22{ }^{14} \mathrm{C}$ yr), the Mediterranean Sea ${ }^{14} \mathrm{C}$ reservoir age displays higher $\mathrm{R}(\mathrm{t})$ values, with a deviance from the global mean sea surface reservoir age $(\Delta \mathrm{R})$ of $58 \pm 85 \mathrm{yr}$. Its western part presents a $\Delta \mathrm{R}$ of $40 \pm 15 \mathrm{yr}$ (Siani et al. 2000; Reimer and McCormac 2002). For the central part of the Gulf of Lion, Siani et al. (2000) found a higher $\Delta \mathrm{R}$ estimated at $245 \pm 30 \mathrm{yr}\left(\mathrm{R}(\mathrm{t})=618 \pm 30{ }^{14} \mathrm{C} \mathrm{yr}\right)$, which is the average of $3 \mathrm{sam}-$ ples collected at Sète and Banyuls and recalculated by using the calibration model of Hughen et al. (2004). This offset from the Marine04 model has been explained as a result of biological processes or hardwater effects due to the discharge of coastal rivers after dissolution of limestone via several brackish lagoons, before reaching this part of the Mediterranean Sea. 
Here, we estimate the modern ${ }^{14} \mathrm{C}$ reservoir age in Pierre Blanche Lagoon by comparing ${ }^{14} \mathrm{C}$ values with both historical events and ${ }^{210} \mathrm{~Pb}$ and ${ }^{137} \mathrm{Cs}$ chronologies. Sabatier et al. (2008) recognized, in several cores, 3 main storm events related to events recorded in historical accounts in AD 1742, 1848, and 1893. In core PRO15, collected $<100 \mathrm{~m}$ away from core PB06, 1 shell (SacA 6270) was recovered at $62 \mathrm{~cm}$ depth, just above the $\mathrm{AD} 1848$ event. This shell dated to $1095 \pm 30{ }^{14} \mathrm{C} \mathrm{yr}$ (Table 3). On the other hand, the youngest age on PB06 at $20.5 \mathrm{~cm}$ depth is $1055 \pm 30{ }^{14} \mathrm{C}$ yr. This age corresponds to a date of AD $1930 \pm 5 \mathrm{yr}$, derived from the ${ }^{210} \mathrm{~Pb}$ CFCS model ages and the ${ }^{137} \mathrm{Cs}$ chronology (average sedimentation rate of $2.65 \pm 0.2 \mathrm{~mm} / \mathrm{yr}$ ).

Sea surface reservoir ${ }^{14} \mathrm{C}$ ages $\mathrm{R}(\mathrm{t})$ for the first modern shell (SacA 6270) on core PRO15 were calculated by subtracting the atmospheric ${ }^{14} \mathrm{C}$ value estimated for the historical date $\mathrm{AD} 1848$ (113 \pm 9 ${ }^{14} \mathrm{C}$ yr, Reimer et al. 2004) from the measured apparent ${ }^{14} \mathrm{C}$ ages of the mollusks $\left(1095 \pm 30{ }^{14} \mathrm{C} \mathrm{yr}\right.$, Table 3, Figure 3). This gives a $\mathrm{R}(\mathrm{t})$ value of $982 \mathrm{yr}$. The deviance from the global mean reservoir age $(\Delta R)$ is then obtained by subtracting the marine model age value estimated for $A D 1848$ $\left(485 \pm 24{ }^{14} \mathrm{C}\right.$ yr, Hughen et al. 2004) from the measured apparent ${ }^{14} \mathrm{C}$ age of the shell $(1095 \pm 30$ ${ }^{14} \mathrm{C}$ yr, Table 3, Figure 3). The $\Delta \mathrm{R}$ value is thus estimated as $610 \pm 40 \mathrm{yr}$ (Figure 3). By adopting a similar approach for shell (SacA 6253) on core PB06 dated to AD 1930 by ${ }^{210} \mathrm{~Pb}$ and ${ }^{137} \mathrm{Cs}$ chronologies (Table 3), we obtain $\mathrm{R}(\mathrm{t})=903{ }^{14} \mathrm{C} \mathrm{yr}(\Delta \mathrm{R}=600 \mathrm{yr})$. These 2 dated shells suggest that in Pierre Blanche Lagoon, the average reservoir age $\mathrm{R}(\mathrm{t})$ is $943 \pm 25{ }^{14} \mathrm{C} \mathrm{yr}(\Delta \mathrm{R}=605 \pm 30 \mathrm{yr})$. This high $\mathrm{R}(\mathrm{t})$ value compared to the Mediterranean Sea in the studied area $\left(\mathrm{R}(\mathrm{t})=618 \pm 30{ }^{14} \mathrm{C} \mathrm{yr}\right.$, Siani et al. 2000) can be explained either by variable discharge of coastal rivers, after draining a watershed mostly composed of limestone, and/or by the non-permanent marine influence in relation to the lagoonal system.

Table $3{ }^{14} \mathrm{C}$ dates of modern pre-bomb shell samples in PBL and their reservoir ages.

\begin{tabular}{|c|c|c|c|c|c|c|c|}
\hline Lab code & Sample & $\begin{array}{l}\text { Age of } \\
\text { shells } \\
\text { (yr AD) }\end{array}$ & $\begin{array}{l}{ }^{14} \mathrm{C} \text { age } \\
\text { (BP) }\end{array}$ & $\begin{array}{l}\text { Tree-ring } \\
{ }^{14} \mathrm{C} \text { age (BP) } \\
\text { IntCal04 }\end{array}$ & $\begin{array}{l}\text { Reservoir } \\
\text { age } \\
\mathrm{R}(\mathrm{t})(\mathrm{yr})\end{array}$ & $\begin{array}{l}\text { Model age } \\
\text { Marine04 }\end{array}$ & $\begin{array}{l}\Delta \mathrm{R} \\
(\mathrm{yr})\end{array}$ \\
\hline SacA 6270 & PRO15-60 & 1848 & $1095 \pm 30$ & $113 \pm 9$ & 982 & $485 \pm 24$ & 610 \\
\hline SacA 6253 & PB06-20 & 1930 & $1055 \pm 30$ & $152 \pm 7$ & 903 & $454 \pm 23$ & 601 \\
\hline
\end{tabular}

\section{Reservoir Age Correction During the Holocene}

In order to apply an accurate $\Delta \mathrm{R}$ correction for ${ }^{14} \mathrm{C}$ dating of marine shells, it is necessary to estimate past R(t) fluctuations (Goodfriend and Flessa 1997; Ingram and Southon 1997; Siani et al. 2001; Reimer and McCormac 2002; Southon et al. 2002; Fontugne et al. 2004). The same precaution has to be taken in coastal areas especially when high $\mathrm{R}(\mathrm{t})$ variability may occur.

From a sedimentological point of view, core PB06 (Figure 4) displays a relatively homogenous lagoonal deposit characterized by gray clays and silts with some sand layers (corresponding to paleostorm events). However, the high-resolution stratigraphy of fauna indicates a clear shift in mollusk population between 190 and $170 \mathrm{~cm}$ (Sabatier et al. 2010) with an increase of lagoonal species (Hydrobia acuta), whereas the number of marine species (Bittium recticulatum) decreases (Figure 4a). These data suggest a variation in environmental conditions (salinity, temperature, nutriments, oxygen content). This change is interpreted as the result of the final closure of the coastal lagoon by a sandy barrier due to sediment transfer along the littoral. In this area, sandy barriers build up as a result of along-shore progradation of sand spits from inherited topographic highs, by east-west coastal drift carrying sand material from the Rhône River (Raynal et al. 2009). Therefore, the fauna content clearly shows a shift from a protected lagoon (with permanent inlet) to an isolated lagoon environment at around 170-cm core depth. 


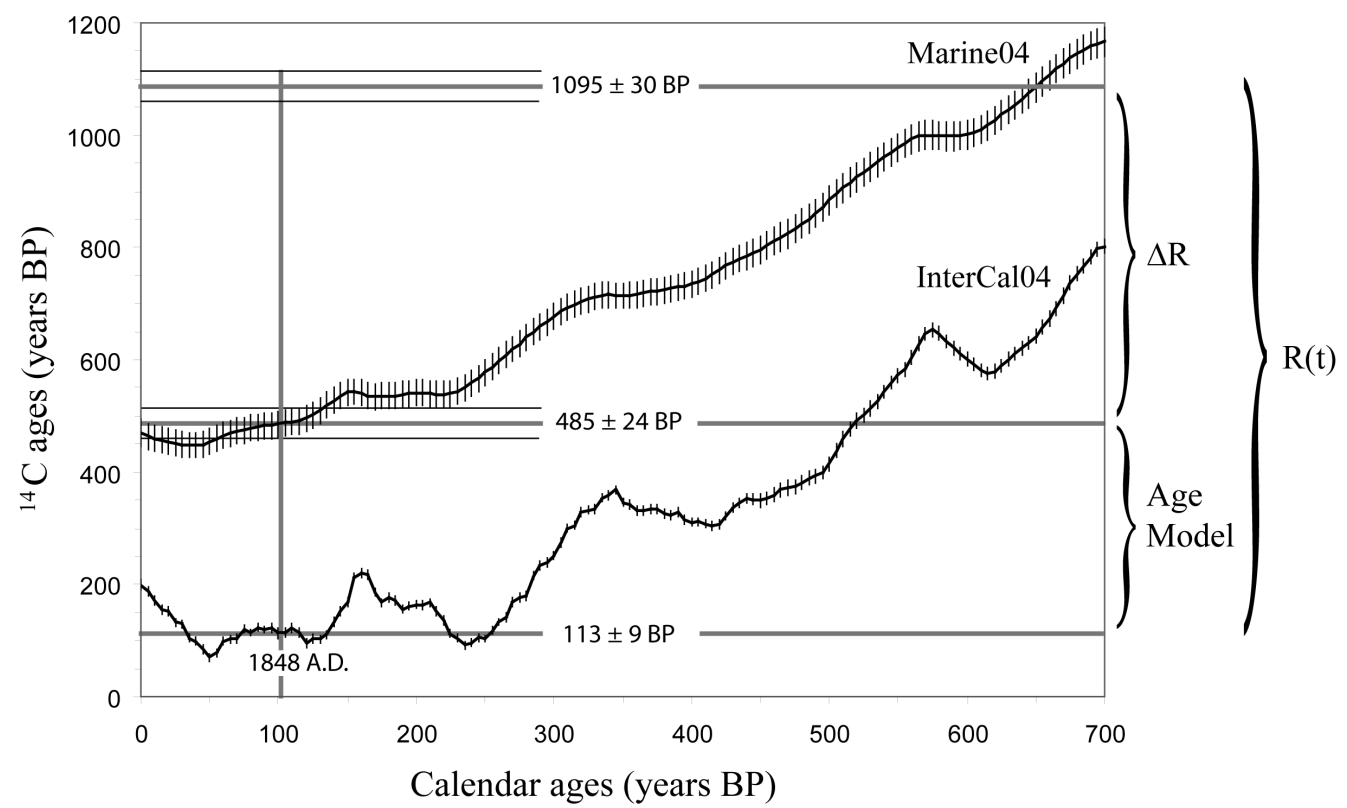

Figure 3 Conversion of ${ }^{14} \mathrm{C}$ conventional ages into calendar ages for subaerial samples equilibrated with atmosphere (lower curve) and marine samples (upper curve). The age difference between the 2 curves for a given calendar date corresponds to the marine reservoir age R(t). Dating of the AD 1848 mollusk shell SacA 6270 found in core PRO 15 gives a conventional ${ }^{14} \mathrm{C}$ age of $1095 \mathrm{yr}$ and thus a reservoir age of $1095-113=982 \mathrm{yr}$. Deviance from the global mean reservoir age $(\Delta \mathrm{R})$ for this same mollusk shell is obtained by subtracting the marine model age value estimated at the historical date from the measured apparent ${ }^{14} \mathrm{C}$ age, giving $1095-485=610 \mathrm{yr}$.

Correction of the reservoir age, as calculated above $(\Delta \mathrm{R}=605 \pm 30 \mathrm{yr})$, was first applied to the whole ${ }^{14} \mathrm{C}$ data set in core PB06 (Table 2), defined as Age model 1 (Figure 4b). The results indicated the persistence of significant ${ }^{14} \mathrm{C}$ age inversions occurring between 130 and $200 \mathrm{~cm}$ along the core. By taking into account the mollusk fauna record, we can assume that apparent ${ }^{14} \mathrm{C}$ age inversions could be related to a change in $\mathrm{R}(\mathrm{t})$ between the 2 lagoonal paleoenvironments (one open to the sea, the other closed). Therefore, we suggest correcting ${ }^{14} \mathrm{C}$ ages using (1) $\Delta \mathrm{R}=245 \pm 30 \mathrm{yr}$ due to the local marine reservoir age during a protected lagoon environment (similar to the value of $618 \mathrm{yr}$ found for the Gulf of Lion by Siani et al. [2000]), and (2) $\Delta \mathrm{R}=605 \pm 30 \mathrm{yr}$ when isolated lagoonal conditions prevailed. Therefore, Age model 2 (Figure 4c) was calculated using $\Delta \mathrm{R}=245 \pm 30 \mathrm{yr}$ for $173-758 \mathrm{~cm}$ depth and $\Delta \mathrm{R}=605 \pm 30 \mathrm{yr}$ for $0-139 \mathrm{~cm}$ depth. The very slight ${ }^{14} \mathrm{C}$ inversion (Figure 4c) between $139 \mathrm{~cm}$ (i.e. $1036 \pm 107 \mathrm{yr}$ cal BP) and $173 \mathrm{~cm}$ (i.e. $948 \pm 106 \mathrm{yr}$ cal BP) is within the uncertainties.

The ${ }^{14} \mathrm{C}$ chronology presented in Figure $4 \mathrm{c}$ between 250 and $300 \mathrm{~cm}$ displays the same ${ }^{14} \mathrm{C}$ age (between 2500 and $2600 \mathrm{yr}$ cal BP). This apparent strong increase of sedimentation rate around 270 $\mathrm{cm}$ is probably the result of a ${ }^{14} \mathrm{C}$ age plateau. Indeed, between 2350 and $2700 \mathrm{yr}$ cal BP the calibration curve presents a ${ }^{14} \mathrm{C}$ age plateau caused by a strong increase of ${ }^{14} \mathrm{C}$ production in the atmosphere at $2750 \mathrm{yr}$ cal BP (Reimer et al. 2004), known as the "Hallstatt disaster." Another age inversion occurred at around $550 \mathrm{~cm}$, between 4875 and $5275 \mathrm{yr}$ cal BP, and is probably also due to the increase of ${ }^{14} \mathrm{C}$ production in the atmosphere around $5300 \mathrm{yr}$ cal BP, likely a similar scenario previously observed during the "Hallstatt disaster." 


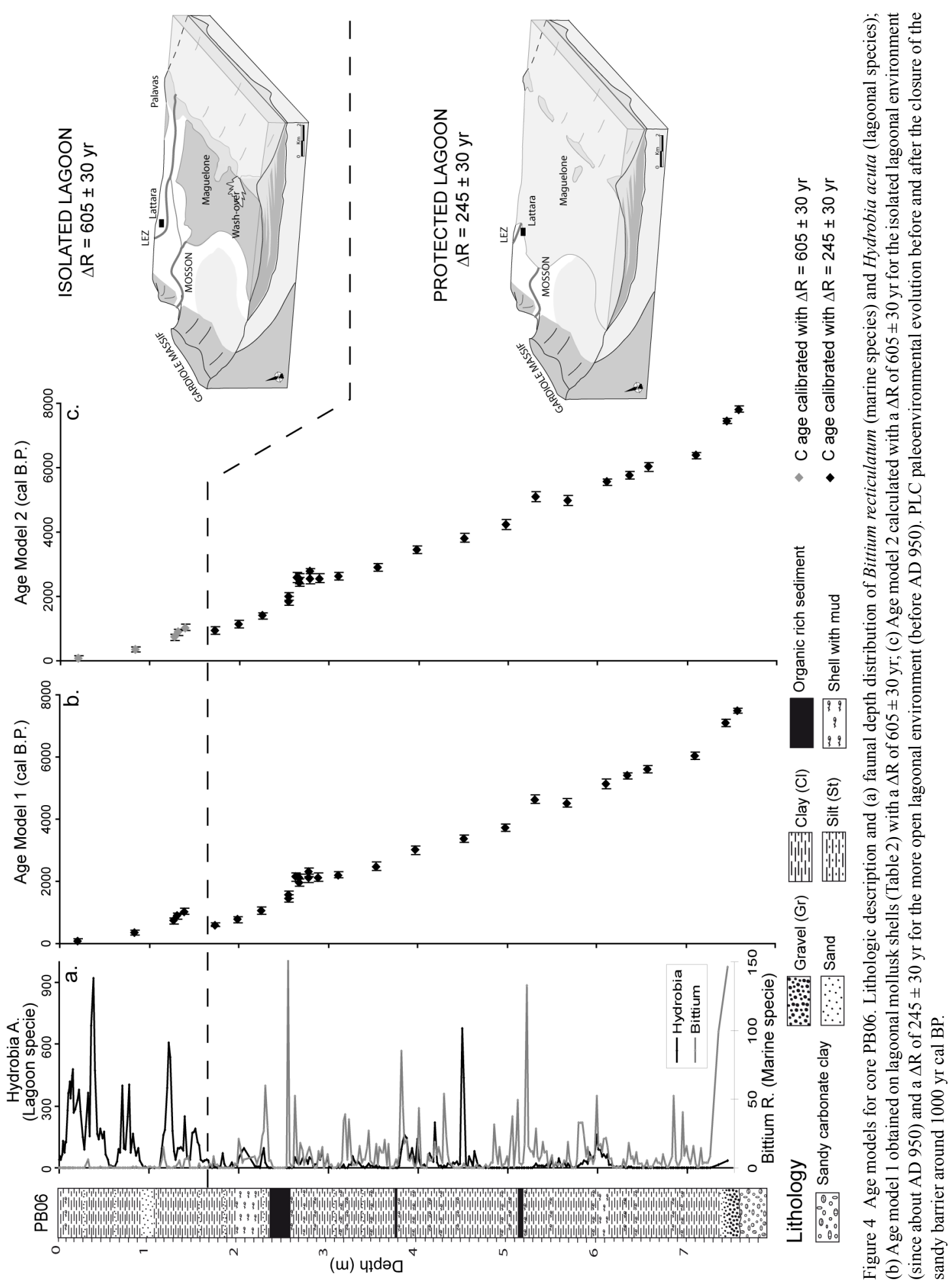


In Pierre Blanche Lagoon, the final model (Age model 2) for PB06 core (Figure 4c) suggest a low sedimentation rate of $0.3 \mathrm{~mm} / \mathrm{yr}$ at the base of the core. This rate increases from $1 \mathrm{~mm} / \mathrm{yr}$ from 6385 to $948{ }^{14} \mathrm{C}$ yr to $1.5 \mathrm{~mm} / \mathrm{yr}$ over the last millennium. For the modern part of the core, the accumulation rate is the same as that estimated at $2.65 \mathrm{~mm} / \mathrm{yr}$ using the ${ }^{210} \mathrm{~Pb}$ and ${ }^{137} \mathrm{Cs}$ chronologies.

\section{$\mathbf{R}(\mathbf{t})$ Comparison with Other Mediterranean Lagoons}

In the northern part of the Lagoon of Venice, Zoppi et al. (2001) estimated a high R(t) value of $\sim 1200 \mathrm{yr}$ by comparing benthic foraminifera and continental leaves at $1900 \mathrm{cal}$ BP. This area seems to be more isolated from the sea than Pierre Blanche Lagoon, with a strong input of freshwater that explains the larger $\mathrm{R}(\mathrm{t})$ values. On the other hand, in the Thau Lagoon (Figure 1), $2{ }^{14} \mathrm{C}$ dates were obtained on continental seed $(2935 \pm 35 \mathrm{BP})$ found at an archaeological site and on a lagoonal shell ( $3535 \pm 35 \mathrm{BP}$, Cerastoderma glaucum). Calculating the $\mathrm{R}(\mathrm{t})$ gives a value of about $600 \pm 50{ }^{14} \mathrm{C} \mathrm{yr}$ (M Court-Picon, unpublished data). Such an $\mathrm{R}(\mathrm{t})$ value is similar to that obtained by Siani et al. (2000) at Sète for the same species but for the modern period (AD 1907-1892: $\mathrm{R}(\mathrm{t})=618 \pm 30{ }^{14} \mathrm{C}$ yr). This value, smaller than the modern value in Pierre Blanche Lagoon, is probably due to a strong marine water input through the large permanent inlet. These $\mathrm{R}(\mathrm{t})$ discrepancies between different Mediterranean lagoonal environments seem to be in good agreement when the lagoons are isolated systems, resulting in an increase in $\mathrm{R}(\mathrm{t})$ when the lagoonal environment is less open to the sea and more influenced by riverine inputs.

\section{CONCLUSION}

The modern ${ }^{14} \mathrm{C}$ reservoir age in Pierre Blanche Lagoon was estimated by comparing ${ }^{14} \mathrm{C}$ ages of 2 mollusk shells with the ages of sediment layers derived from historical storm events and from ${ }^{210} \mathrm{~Pb}$ and ${ }^{137} \mathrm{Cs}$ chronologies. The high value found $\left(943 \pm 25{ }^{14} \mathrm{C} \mathrm{yr}\right)$ compared to the average marine reservoir age results from a hardwater effect caused by the discharge of coastal rivers and/or by the relative isolation of the lagoon from the sea. This interpretation is in good agreement with data reporting high $\mathrm{R}(\mathrm{t})$ values for different Mediterranean lagoons in variable isolation states (Venice, Thau). Our data further suggest that $\mathrm{R}(\mathrm{t})$ has probably changed with time, with an increase of $>350 \mathrm{yr}$ between the mid and late Holocene. This change most likely results from the final closure of the coastal lagoon with the growth of the sandy barrier. The age model of core PB06 indicates a low sedimentation rate of $0.3 \mathrm{~mm} / \mathrm{yr}$ between 7817 and $6385{ }^{14} \mathrm{C} \mathrm{yr}$, corresponding to the last stand of postglacial sea-level rise. The sedimentation rate is then relatively constant at $1 \mathrm{~mm} / \mathrm{yr}$ over a period of protected lagoonal environment (from 6385 to $948{ }^{14} \mathrm{C}$ yr), then increasing to $1.5 \mathrm{~mm} / \mathrm{yr}$ during isolated lagoonal conditions (last millennium). This latter rate is in good agreement with the rate derived from ${ }^{210} \mathrm{~Pb}$ and ${ }^{137} \mathrm{Cs}$ chronologies. This study confirms that a careful estimation of $\mathrm{R}(\mathrm{t})$ is necessary when accurate ${ }^{14} \mathrm{C}$ ages are to be derived in high-resolution studies of coastal areas. This would avoid misinterpretation of archaeological or paleoenvironmental data.

\section{ACKNOWLEDGMENTS}

This research has been undertaken in the framework of the ECLICA Project financed by INSU (ACIFNS "Aléas et Changement Globaux," coordinator L Dezileau) and the ARMILIT project (ANR n NT_NV_27/2005, P Blanchemanche). We thank the Laboratoire de Mesure ${ }^{14} \mathrm{C}$ (LMC14) ARTEMIS in the CEA Institute at Saclay (French Atomic Energy Commission) for the ${ }^{14} \mathrm{C}$ analyses (ECLICA and INTEMPERIES projects, coordinator Dezileau). I Bentaleb thanks the members of the "Paleocean" team, especially Fabien Dewilde, Elsa Cortijo, and Elisabeth Michel for offering their facilities during the academic sabbatical she spent at the CNRS-LSCE. Michel Fontugne (LSCE) and members of the GLADYS platform (www.gladys-littoral.org) and of the ECLICA 
Project are also thanked for their constructive discussions during the course of this study. We are also grateful to J Faïn (Université Blaise Pascal, Clermont-Ferrand) for allowing us to use his program for self-attenuation corrections in $\gamma$-ray spectrometry. This article benefited through constructive reviews by Paula Reimer.

\section{REFERENCES}

Appleby PG. 1991. ${ }^{241}$ Am dating of lake sediments. $H y$ drobiologia 214:35-42.

Appleby P, Oldfield F. 1978. The calculation of lead-210 dates assuming a constant rate of supply of unsupported ${ }^{210} \mathrm{~Pb}$ to the sediment. Catena $5(1): 1-8$.

Appleby P, Oldfield F. 1992. Application of lead-210 to sedimentation studies. In: Ivanovich M, Harmon RS, editors. Uranium Series Disequilibrium, Application to Earth, Marine and Environmental Sciences. Oxford: Clarendon Press. p 773-8.

Certain R, Tessier B, Courp T, Barusseau J, Pauc H. 2004. Reconnaissance par sismique très haute résolution du remplissage sédimentaire de la lagune de Leucate (Aude et Pyrénées-Orientales-SE France). Bulletin de la Société Geologique de France 175:3548.

Dezileau L, Bordelais S, Condomines M, Bouchette F, Briqueu L. 2005. Evolution des lagunes du Golfe d'Aigues-Mortes à partir de l'étude de carottes sédimentaires courtes (étude géochronologique, sédimentologique et géochimique des sédiments récents). Association des Sedimentologistes Français. Volume 51. p 91.

Fontugne M, Carré M, Bentaleb I, Julien M, Lavallée D. 2004. Radiocarbon reservoir age variations in the South Peruvian upwelling during the Holocene. Radiocarbon 46(2):531-7.

Golberg E. 1963. Geochronology with ${ }^{210} \mathrm{~Pb}$. In: Radioactive Dating. Vienna: International Atomic Energy Agency. p 121-31.

Goodfriend GA, Flessa KW. 1997. Radiocarbon reservoir ages in the Gulf of California: roles of upwelling and flow from the Colorado River. Radiocarbon 39(2):139-48.

Hughen KA, Baillie MGL, Bard E, Beck JW, Bertrand CJH, Blackwell PG, Buck CE, Burr GS, Cutler KB, Damon PE, Edwards RL, Fairbanks RG, Friedrich M, Guilderson TP, Kromer B, McCormac G, Manning S, Bronk Ramsey C, Reimer PJ, Reimer RW, Remmele S, Southon JR, Stuiver M, Talamo S, Taylor FW, van der Plicht J, Weyhenmeyer CE. 2004. Marine04 marine radiocarbon age calibration, 0-26 cal kyr BP. $R a$ diocarbon 46(3):1059-86.

Ingram BL, Southon JR. 1997. Reservoir ages in eastern Pacific coastal and estuarine waters. Radiocarbon 38(3):573-82.

Krishnaswamy S, Lal D, Martin JM, Meybeck M. 1971. Geochronology of lake sediments. Earth and Planetary Science Letters 11(1-5):407-14.

Little EA. 1993. Radiocarbon age calibration at archaeo- logical sites of coastal Massachusetts and vicinity. Journal of Archaeological Science 20(4):457-71.

Mangerud J. 1972. Radiocarbon dating of marine shells, including a discussion of apparent ages of Recent shells from Norway. Boreas 1(2):143-72.

Oldfield F, Asioli A, Accorsi CA, Mercuri AM, Juggins S, Langone L, Rolph T, Trincardi F, Wolff G, Gibbs Z, Vigliotti L, Frignani M, van der Post K, Branch V. 2003. A high resolution late Holocene palaeo environmental record from the central Adriatic Sea. Quaternary Science Reviews 22(2-4):319-42.

Pilleyre T, Sanzelle S, Miallier D, Faïn J, Courtine F. 2006. Theoretical and experimental estimation of selfattenuation corrections in determination of ${ }^{210} \mathrm{~Pb}$ by $\gamma-$ spectrometry with well Ge detector. Radiation Measurements 41(3):323-9.

Radakovitch O, Charmasson S, Arnaud M, Bouisset P. 1999. ${ }^{210} \mathrm{~Pb}$ and caesium accumulation in the Rhône Delta sediments. Estuarine, Coastal and Shelf Science 48(1):77-92.

Raynal O, Bouchette F, Certain R, Séranne M, Dezileau L, Sabatier P, Lofi J, Hy ABX, Briqueu L, Pezard P, Tessier B. 2009. Control of alongshore-oriented sand spits on the dynamic of a wave-dominated coastal system (Holocene deposits, northern Gulf of Lions, France). Marine Geology 264(3-4):242-57.

Reimer PJ, McCormac FG. 2002. Marine radiocarbon reservoir corrections for the Mediterranean and Aegean seas. Radiocarbon 44(1):159-66.

Reimer PJ, Reimer RW. 2001. A marine reservoir correction database and on-line interface. Radiocarbon 43(2A):461-3.

Reimer PJ, Baillie MGL, Bard E, Bayliss A, Beck JW, Bertrand CJH, Blackwell PG, Buck CE, Burr GS, Cutler KB, Damon PE, Edwards RL, Fairbanks RG, Friedrich M, Guilderson TP, Hogg AG, Hughen KA, Kromer B, McCormac G, Manning S, Bronk Ramsey C, Reimer RW, Remmele S, Southon JR, Stuiver M, Talamo S, Taylor FW, van der Plicht J, Weyhenmeyer CE. 2004. IntCa104 terrestrial radiocarbon age calibration, 0-26 cal kyr BP. Radiocarbon 46(3):1029-58.

Robbins J, Edgington D. 1975. Determination of recent sedimentation rates in Lake Michigan using $\mathrm{Pb}-210$ and Cs-137. Geochimica et Cosmochimica Acta 39(3):285-304.

Sabatier P, Dezileau L, Condomines M, Briqueu L, Colin C, Bouchette F, Le Duff M. Blanchemanche P. 2008. Reconstruction of paleostorm events in a coastal lagoon (Hérault, south of France). Marine Geology 251(3-4):224-32. 
Sabatier P, Dezileau L, Barbier M, Raynal O, Lofi J, Briqueu L, Condomines M, Bouchette F, Certain R, Van Grafenstein U, Jorda C, Blanchemanche P. 2010. Late-Holocene evolution of a coastal lagoon in Gulf of Lions (south of France). Bulletin de la Société Geologique de France 181(1):27-36.

Siani G, Paterne M, Arnold M, Bard E, Métivier B, Tisnerat N, Bassinot F. 2000. Radiocarbon reservoir ages in the Mediterranean Sea and in Black Sea. Radiocarbon 42(2):271-80.

Siani G, Paterne M, Michel E, Sulpizio R, Sbrana A, Arnold M, Haddad G. 2001. Mediterranean sea surface radiocarbon age changes since the last glacial maximum. Science 294(5548):1917-20.

Sorrel P, Tessier B, Demory F, Delsinne N, Mouazé D. 2009. Evidence for millennial-scale climatic events in the sedimentary infilling of a macrotidal estuarine system, the Seine estuary (NW France). Quaternary Science Reviews 28(5-6):499-516.

Southon J, Kashgarian M, Fontugne M, Metivier B, Yim WW-S. 2002. Marine reservoir corrections for the Indian Ocean and Southeast Asia. Radiocarbon 44(1): $167-80$.
Spennemann DHR, Head MJ. 1998. Tongan pottery chronology, ${ }^{14} \mathrm{C}$ dates and the hardwater effect. Quaternary Geochronology 17(11):1047-56.

Stuiver M, Braziunas TF. 1993. Modelling atmospheric ${ }^{14} \mathrm{C}$ influences and ${ }^{14} \mathrm{C}$ ages of marine samples to 10,000 BC. Radiocarbon 35(1):137-89.

Stuiver M, Polach HA. 1977. Discussion: reporting of ${ }^{14} \mathrm{C}$ data. Radiocarbon 19:355-63.

Stuiver M, Reimer PJ. 1993. Extended ${ }^{14} \mathrm{C}$ data base and revised CALIB $3.0{ }^{14} \mathrm{C}$ age calibration program. $R a$ diocarbon 35(1):215-30.

Stuiver M, Pearson GW, Braziunas T. 1986. Radiocarbon age calibration of marine samples back to $9000 \mathrm{cal} \mathrm{yr}$ BP. Radiocarbon 28(2B):980-1021.

Tisnérat-Laborde N, Poupeau JJ, Tannau JF, Paterne M. 2001. Development of a semi-automated system for routine preparation of carbonate samples. Radiocarbon 43(2A):299-304.

Zoppi U, Albani A, Ammerman AJ, Hua Q, Lawson EM, Serandrei Barbero R. 2001. Preliminary estimate of the reservoir age in the Lagoon of Venice. Radiocarbon 43(2A):489-94. 